\title{
Genetic Progress in 53 Years of the Peach Breeding Program of Embrapa: Canning Genotypes
}

\section{Maicon Nardino ( $\nabla$ nardino@ufv.br)}

Universidade Federal de Vicosa https://orcid.org/0000-0002-4177-4921

\section{Elisia Rodrigues Corrêa}

Federal University of Pelotas: Universidade Federal de Pelotas

\section{Maria do Carmo Bassols Raseira}

EMBRAPA Centro de Pesquisas Agropecuarias do Clima Temperado

Isadora Moreira da Luz Real

Federal University of Pelotas: Universidade Federal de Pelotas

\section{Willian Silva Barros}

Federal University of Pelotas: Universidade Federal de Pelotas

\section{Rodrigo Cezar Franzon}

EMBRAPA Centro de Pesquisas Agropecuarias do Clima Temperado

\section{Research Article}

Keywords: Prunus persica, genetic gain, peach breeding, fruit development period

Posted Date: July 8th, 2021

DOl: https://doi.org/10.21203/rs.3.rs-673135/v1

License: (c) (i) This work is licensed under a Creative Commons Attribution 4.0 International License.

Read Full License 


\section{Title Page}

\section{Genetic progress in 53 years of the peach breeding program of Embrapa: canning} genotypes

Maicon Nardino $^{1 *}$, Elisia Rodrigues Corrêa ${ }^{2}$, Maria do Carmo Bassols Raseira ${ }^{3}$, Isadora Moreira da Luz Real ${ }^{2}$, Willian Silva Barros ${ }^{2}$, Rodrigo Cezar Franzon ${ }^{3}$

${ }^{1}$ Department of Agronomy/DAA, Federal University of Viçosa/UFV Avenida Peter Henry Rolfs, s/n. 36570-000. Viçosa -MG, Brazil. E mail: nardino@ufv.br

${ }^{2}$ Institute of Physics and Mathematics, Department of Mathematics and Statistics/IFM-DME, Federal University of Pelotas/UFPel, Campus Capão do Leão, s/n. 96160-000 Capão do LeãoRS. Brazil. Email: $\quad$ elisiarc@hotmail.com, isadora.real18@hotmail.com, wsbarros@hotmail.com

${ }^{3}$ Embrapa Temperate Agriculture, BR 392 km 78, 96010-971 Pelotas-RS. Brazil. E mail: maria.bassols@embrapa.br, rodrigo.franzon@embrapa.br

Corresponding author: Maicon Nardino

E mail: nardino@ufv.br

Authors' ORCID: Maicon Nardino (0000-0002-4177-4921); Elisia Rodrigues Corrêa (00000002-4358-5753); Maria do Carmo Bassols Raseira (0000-0002-0648-5526); Isadora Moreira da Luz Real (0000-0002-6333-9437); Willian Silva Barros (0000-0003-1057-6006); Rodrigo Cezar Franzon (0000-0002-0942-9714); 
Abstract. Peach is a traditional crop in the south of Rio Grande do Sul State, Brazil, where 30 to 53 million cans of peaches in syrup are produced annually. All the raw material produced in the region consists of fruits originating from the peach breeding program of the Brazilian Agricultural Research Corporation (Embrapa Temperate Agriculture), which started even before Embrapa at the Experimental Station of Pelotas, Ministry of Agriculture. The objective was to estimate the genetic progress in phenological traits and production of canning peach resulting from the peach breeding program of Embrapa Temperate Agriculture in 53 years. We divided the data records considered in the estimation of genetic progress into two periods, 19641984 and 1985-2017, totaling 53 years. The following traits: maturing period, cycle, number of fruits, fruit weight, yield, and soluble solids content were evaluated. We initially tabulated data and analyzed descriptive statistics. Subsequently, we conducted analysis of mixed models and obtained the estimates of genetic progress through meta-analysis. Genetic gain for earliness, shortening the cycle from flowering to maturation, and genetic gain for fruit yield were observed.

Keywords: Prunus persica; genetic gain; peach breeding; fruit development period

\section{Declarations}

Funding: This work was carried out with the support of the Coordination for the Improvement of Higher Education Personnel (CAPES).

Conflicts of interest: The authors declare that they have no competing interest and agreed to the publication of the manuscript in journal.

Availability of data and material: Not applicable.

Code availability: Not applicable.

\section{Acknowledgments}

We thank Gilberto Kuhn, Everton Pederzolli and staff support with field work for helping with data collection or orchard management. We also thank the previous breeders Sergio Sachs, Bonifacio Nakasu and Ascunia Feliciano.

There is no conflict of interest 


\section{Introduction}

The peach breeding program officially started in the municipality of Pelotas at the Experimental Station of Pelotas (today part of Embrapa Temperate Agriculture) in 1963, although germplasm introduction had already been conducted before this date.

Initially, the priority of this program was to develop cultivars for production of canning peaches with the main goals of adapting fruits to the mild winter conditions and extending the harvest period. Dr. Sérgio Sachs, who at the time led the program, managed to introduce a valuable germplasm of American origin, followed by the introduction of hundreds of seeds by the breeder Bonifácio H. Nakasu. This germplasm, added to what already existed in the country, ensured the initial variability of the working collection, which has been increasing over the years through other additions. However, one of the difficulties at the time was that most of the material introduced consisted of table fruit producing genotypes. One of the procedures adopted was to cross table and canning fruit genotypes and cross the next generation again with an processing-type fruit cultivar or selection (Raseira et al., 2014). Thus, the breeders obtained canning-type cultivars and selections with early or very early maturation (Raseira, 2010; Raseira et al., 2015, 2018).

Over the years, other priorities have been added to the initial goals, such as fruit size, pulp firmness, disease resistance, yield, total soluble solids content, increased pulp-stone ratio, and production stability. The cycle from flowering to maturation also stirred interest since the longer the cycle, the longer the fruit remains in the orchard and the greater the risk of losses caused by climatic phenomena such as strong winds, hail (Raseira et al., 2014), and/or biotic factors. Very early flowering, although being related to low chilling requirement, is undesirable in some cultivation areas due to the occurrence of frosts (Raseira, 2010).

Thus, low chilling requirement and late flowering (due to high heat requirement for flowering - Growing degree hours, GDH) may be ideal, as long as the short cycle with rapid fruit growth does not lead to the incidence of what is known as "split stone". The objective of this work was to estimate the genetic progress in 53 years of the peach breeding program of Embrapa Temperate Agriculture for fruit producing cultivars intended for processing and canning.

\section{Material and Methods}

\section{Plant material}

Initially, we worked on data of 1687 genotypes obtained in 53 years, being 104 canning cultivars, 298 table fruit cultivars, 613 table fruit selections, and 672 canning selections. However, as many selections are preserved only for new hybridizations due to fruit quality or 
other traits, not being included in the object of this study and not having the perspective of becoming cultivars, we subsequently decided to only use cultivars that received variety denomination. Nevertheless, the number of data was very large and we decided to separately study table genotypes from those intended for canning (fruit produced for processing).

In the present study on genetic progress, we only considered canning peach genotypes released by the Embrapa Temperate Agriculture program. Thus, we analyzed 52 canning cultivars. During the period from 1964 to 1984, the plants were established in the current

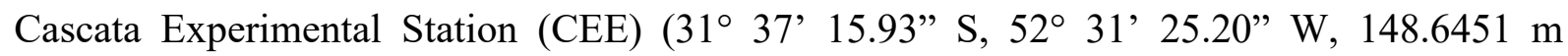
altitude). After this period, the same cultivars were accompanied at the headquarters of Embrapa Temperate Agriculture (ETA) (31 ${ }^{\circ} 42^{\prime}$ S, 52 $2^{\circ} 24^{\prime}$ W, 57 m altitude) (1985 to 2017).

Collections of the two locations differ both in phytotechnical parameters, such as reduction of spacing between plants from four meters (CEE) to three meters (ETC), as well as in the soil type and its physical and chemical characteristics. At ETC, the soil is shallower and chemically poorer (at a depth of $30 \mathrm{~cm}$ ), being heavy and moist after this depth, from which roots have difficulty penetrating. However, fertilization remained the same, based on leaf analysis. The two locations also differ in altitude $(150 \mathrm{~m}$ and $60 \mathrm{~m})$, which is reflected in the temperature, generally $2{ }^{\circ} \mathrm{C}$ higher at the ETC, consequently decreasing chilling accumulation by 100 hours (Embrapa, 2020).

We analyzed genetic progress considering the genotypes listed in Table 1.

\section{Data collection}

The phenological monitoring of the cultivars is conducted yearly observing the dates of beginning of flowering and full flowering and the beginning and end of maturation. Annually, fruits from each cultivar are evaluated regarding fruit color, shape, and size, pulp firmness, total soluble solids content, flavor, adherence to the endosperm, firmness, and health.

In the present study, we analyzed the following variables: beginning of maturation (MAT), considering the number of days from January $1^{\text {st }}$ to the beginning of the first harvest of the cultivar in the current season; fruit development period (FDP I), number of days between the beginning of flowering and the beginning of harvest, which we have agreed to name initial cycle; fruit development period considered from full flowering (FDP II), corresponding to the number of days between full flowering (more than $50 \%$ open flowers) and the beginning of harvest; total soluble solids (TSS), which is measured in ${ }^{\circ}$ Brix using a digital refractometer on three to five fruits per cultivar and year; average fruit mass (FM) in grams, determined using an analog scale and a sample of 10 to 20 fruits per cultivar and per season; number of fruits (NF), obtained by counting the number of fruits per plant (unit), and production (PD) per plant, 
obtained by multiplying the number of fruits per plant by their average mass $(\mathrm{Kg})$, from $P D=$ $F M \times N F$.

We highlight that in the initial period, from 1964 to 1984, the number of fruits was counted during fruit thinning. The number of fruits removed from the plant was counted and the remaining fruits were counted afterwards. For this purpose, a manual counter was frequently used to help record the numbers. However, fruit counting is very difficult in this period as the plant presents many leaves and the fruits are green. Thus, failures may have occurred. In addition, fruit may fall until harvest, which may have overestimated production at times in this period. However, with the increase in the number of genotypes and reduction of human resources to conduct this task, those counting became almost impossible in the second period. Our option was to assign a degree of production on a scale of 1 to 5 , where $\mathrm{G} 1=50$ fruits; $\mathrm{G} 2$ $=100$ fruits; G3 = 250 fruits; G4 = 300 fruits; and G5 equal to or above 450 fruits. This scale was attributed to be compatible with the 1964-1984 period, but it limited the largest productions.

Data were recorded in a physical file. For analysis, they were digitized in an Excel® spreadsheet.

\section{Statistical analysis}

Data analysis - genetic progress

Data were grouped from the historical series of the breeding program according to the year of inclusion of the genotype in the evaluation. We initially tabulated data and analyzed the descriptive statistics, considering each variable individually. Subsequently, we performed analysis by mixed linear models generalized by PROC GLIMMIX from the SAS software. The generalized linear mixed model used was:

$$
y_{i j}=m+g_{i}+y_{j}+\varepsilon i_{i j}
$$

where $\mathrm{y}_{\mathrm{ij}}$ is the observed data of the variable in genotype $i$ in year $j, m$ is the intercept or the general mean, $g_{i}$ is the random effect of genotype $g i \sim \operatorname{IIDN}\left(0, \sigma_{g}^{2}\right), \mathrm{y}_{\mathrm{j}}$ is the fixed effect of year $j$ and $\varepsilon_{\mathrm{ij}}$ is the effect of the random error $\varepsilon \sim \operatorname{IIDN}\left(0, \sigma_{\varepsilon}^{2}\right)$.

The methodology for estimating genetic progress adopted was according to Breseghello et al. (1999). We conducted the following procedures on the SAS software (SAS Institute, 2014) with generalized mixed linear models for each variable using the following commands: PROC GLIMMIX DATA = NAME; CLASS GEN YEAR; MODEL VAR = YEAR/DIST = NORMAL; LSMEANS YEAR/CL COV; RANDOM GEN/SOLUTION CL; RUN;

After application of the generalized mixed linear model, in which genotype means for each year were fitted and covariance matrices were obtained, an estimate of the average annual genetic progress was conducted through analysis of the generalized linear regression. The 
average annual genetic progress was estimated by the linear regression coefficient $b_{1}$ of $\hat{Y}_{K}^{*}$, given by the ratio between the $\mathrm{b}_{1}$ (slope) and the $\mathrm{b}_{0}$ (intercept) from the initial phase of the breeding program for the year 64 (phase 1) and 84 (phase 2), where $\mathrm{b}_{1}$ was obtained by the generalized least squares method (Hoffamann and Vieira, 1987). When the value of b was significant, the intercept of the regression regarding the initial theoretical value of the studied period was calculated as follows:

$$
\hat{\beta}=\frac{\widehat{b_{1}}}{\widehat{b_{0}}}=\left(X^{\prime} X D^{-1}\right)^{-1}\left(X^{\prime} D^{-1} \widehat{Y}^{*}\right)
$$

where $\widehat{b_{1}}$ is the coefficient for average weights $\widehat{Y}_{K}^{*}$ according to the year, in order to estimate the average annual genetic gain, and $X$ is the matrix of dimension a $\mathrm{x} 2$, which consists of a column vector of relative and $\widehat{b_{0}}$ a column vector of $1,2, \ldots$, a related to $b_{1}$, where a is the number of years. The significance of the model was obtained by the $t$ test.

\section{Data analysis - most important genotype}

Among all the genotypes released commercially, some were highlighted for traits that made them more important for the breeding program or made them have a higher rate of adoption by producers. These genotypes were separated in an electronic spreadsheet in order to conduct another analysis according to commands from the R software (Olivoto and Lúcio, 2020). In this analysis, the year information was consider fixed effect and genotype a random effect $\mathrm{N}\left(0, \sigma_{g}^{2}\right)$. After obtaining BLUP values for the genotype, the confidence intervals (95\%) were obtained and the graphics were built using the ggplot package (Wickham, 2016).

After obtaining the BLUP values of the most important genotypes, genotypic distance was analyzed using the Euclidean distance through the factoextra package and hierarchical grouping through multi-scale bootstrap using the $p v \_c l u s t$ package with alpha of 0.95 and nboot 100.

\section{Results}

We divided the results of the breeding program into the two following periods: the $1^{\text {st }}$ period, from 1964 to 1984 , and the $2^{\text {nd }}$ period, from 1985 to 2017 , due to the change of location (environment) of the germplasm, whose differences we mentioned in the Material and Methods section. Subsequently, we conducted the stratification of gain estimates for each period separately, coding them as 1964 and 1985, respectively. We divided results by period and by trait, as described below.

The variance components of random factors obtained by the generalized linear mixed models are shown in Table 2. For the variance components of traits related to the cycle, we observed a greater proportion of genotypic effects compared to environment effects. On the 
other hand, environment variance strongly influenced production variables, that is, environment effects provided great variations in the expression of these traits during the evaluated period. For the fixed year effect, we observed significant effect on the factor for all the traits evaluated in all periods according to the $\mathrm{F}$ test (Table 2).

\section{Descriptive statistics and comparison between years of the general means}

Maturation: Among the genetic material of the Embrapa breeding program, we observed from early-maturing genotypes (267 days, corresponding to the end of September) to late-maturing genotypes (422 days, corresponding to February). The earliest genotype presented flowering on June 6 and maturation on September 27, while the latest presented flowering on August 2 and maturation on February 26, with a difference of 155 days between the earliest and the latest (Table 3). Regarding the number of days for maturation, we observed a small increase in the number of days in the 1964-1984 period, while the number of days for maturation decreased in the 1985-2017 period, mainly from the genotypes released after 2010 (Figure $1 \mathrm{a}$ and $\mathrm{b}$ ).

Fruit Development Period: Regarding FDP I_1964, the genotypes with the lowest values presented 100-day of FDP and the genotypes with the highest values presented 209-day of FDP, that is, a difference of 109 days. On the other hand, in FDP I_1985 the minimum values were 77 days and the maximum 219 days, that is, a difference of 142 days (Table 3). In the analysis of FDP_I, we observed reduction in the 1964-1984 period and also observed reduction between 1985-2017 (Figure $1 \mathrm{c}$ and d).

Regarding FDP II_1964, the genotypes with the lowest values presented 89-day of FDP and the genotypes with the highest values presented 199-day of FDP, that is, a difference of 110 days. On the other hand, in FDP I_1985, the minimum values were 66 days and the maximum was 203 days, with a difference of 137 days (Table 2). For the analysis of results of the FDP_II, we observed reduction in the two periods, that is, from 1964-1984 and 1985-2017, with the greatest reduction in the second period (Figure $1 \mathrm{e}$ and $\mathrm{f}$ ).

Number of fruits (NF): Due the different evaluation methods between periods, it was observed considerable variation between absolute values, with a higher NF in the first period (Table 3). Regarding results of NF per plant, we observed increase in the number of fruits per plant between 1964-1984. For the second period, 1985-2017, the NF per plant remained stable, and we highlight that the values were lower than for the first period (Figure $2 a$ and $b$ ).

Average fruit weight: For FW_1964, we observed minimum values 30 grams lighter than for the 1985 period, in which we observed minimum values of 37 grams. Maximum values of 216 grams and 288 grams for the periods 1964 and 1985, respectively (Table 3) were 
observed. Regarding FW, we observed stable weight in 1964-1984, although observing variation in some years. We observed a trend of increasing FW in the second period (Figure 2 c and d).

Production per plant: For the variable PD_1964, the minimum value of 0.73 kilograms/plant, was observed which was approximate to the minimum values in $1985,0.82$ kilograms/plant. The maximum values were 123.30 kilograms/plant for PD_1964 and 101.91 kilograms for PD_1985 (the use of a scale of degree of production decreased the amplitude) (Table 2). Regarding PD per plant, it was observed an increase in total production in the 19641984 period, which was also observed for the 1985-2017 period, mainly from 2010, when genotypes presented higher average production, considering the average for the year (Figure 2 e and $f$ ).

Total soluble solids content in fruits: Regarding TSS, minimum value of $5.7^{\circ}$ Brix and maximum value of $19.9^{\circ}$ Brix were obtaining, presenting amplitude of $14.2^{\circ}$ Brix (Table 3). The total soluble solids content was only determined in the second period, 1985-2017. We observed a trend towards reduction of TSS content considering the average value of the analyzed years (Figure $2 \mathrm{~g}$ ), with great variation between years.

\section{Genetic Gain}

The results of genetic gain estimates for the 1964-1984 and 1985-2017 periods for the traits studied are shown in Table 4.

We observed that the slope was positive for maturing in the 1964-1984 period, resulting in a positive annual gain of $0.05(\%)$ year, that is, the result showed a trend of a later beginning of maturing, with predominance of late-maturing genotypes. On the other hand, we observed a negative slope for the 1985-2017 period with an estimated genetic gain of $-0.05(\%)$ year, that is, the genotypes released in this period were predominantly of early maturing.

In the analysis of genetic gain for the cycle, considering the beginning of flowering, we observed a negative slope, as well as an annual genetic gain of -0.09 and $-0.08 \%$ for the $1964-$ 1984 and 1985-2017 periods, respectively. If we compare this result with a previous study (Corrêa et al., 2019) considering a period of 16 years starting in 2000 and 24 canning genotypes, nine of which are cultivars and the others advanced selections from the program, we can assume that the fruit development period was more strongly reduced $(-12,7 \%)$ between 2000 and 2015 .

Regarding the cycle from full flowering, we observed that the number of days until flowering reduced in both periods with genetic gains of -0.02 and $-0.14 \%$, respectively, for the first and second period. 
For the number of fruits, we observed a high genetic gain of $7.97 \%$ during the first

period, that is, breeding was directed towards production of genotypes with a greater number of fruits per plant. On the other hand, we also observed a gain of $0.39 \%$ in the second period, although being well below the first period, which means that breeding worked towards other traits of interest.

In the analysis of fruit weight, we observed a negative genetic gain of $-0.13 \%$ from 1964-1984, most likely due to the increase in the number of fruits per plant. For the 1985-2017 period, a positive genetic gain of $0.38 \%$, was achieved, which may be aligned with a smaller number of fruits and consequently heavier fruits, and also with the fact that cultivars obtained from the 1980s have greater potential for fruit size. This gain was considerably higher in the 24 genotypes studied between 2000 and 2015 (5.3\%), possibly because only the most important genotypes were selected for the study (Corrêa et al., 2019).

Regarding fruit yield, a gain of $19.38 \%$ was observed in the first period, 1964-1984, and also a positive genetic gain of $1.23 \%$ for the second period, 1985-2017.

In the evaluation of TSS content obtained for the second period, 1985-2017, we observed a reduction of genetic gain in the genotypes, corresponding to $-0.11 \%$ per year. We expected this reduction due to the negative association with the days until maturing, which was negative in this period as already highlighted.

\section{Highlighted genotypes}

Regarding the evaluation of genotypes highlighted for their importance for the peach breeding program of Embrapa or that were the most planted by fruit growers and are still currently found in the area (even if in a few orchards), Best Linear Unbiased Prediction (BLUP) results for each trait are shown individually in Figure 3.

For beginning of harvest (Figure 3 a), great differences were observed between genotypes. For example, the genotype 'BRS Libra' presented 290 days until maturity (corresponding to October 18), while genotypes 'Magno' and 'BR 6' reach maturity after approximately 380 days (corresponding to January 26th of the year following the beginning of counting), that is, approximately 90 days of difference. The mean BLUP value was 340 days from January 1 until maturity.

Regarding the initial cycle (Figure $3 \mathrm{~b}$ ), the genotypes 'BRS Libra' and 'Pepita' presented a cycle of approximately 100 days from the beginning of flowering until harvest. On the other hand, the genotypes 'Cerrito' and 'Turquesa' presented a mean cycle of 180 days, with the mean BLUP value of approximately 140 days. 
Regarding the date of full flowering (Figure $3 \mathrm{c}$ ), great differences were observed between genotypes, with the earliest flowering being observed for cultivars 'Pepita' and 'BRS 'Libra', 100 days, and the latest full flowering date being observed for cultivar 'Cerrito' and 'Turquesa', approximately 180 days. The mean BLUP value was of 128 days from January $1^{\text {st }}$ until full flowering.

In the evaluation of total soluble solids content (Figure $3 \mathrm{~d}$ ), genotypes 'BR 6', 'Olimpia', and 'Cerrito' presented the highest content. On the other hand, genotypes 'Precocinho' and 'BRS Citrino presented the lowest TSS contents. The mean BLUP value was $12.5^{\circ}$ brix.

Regarding the analysis of the most relevant genotypes for the average fruit weight (Figure 3 e), the heaviest weights were observed for cultivars Âmbar, Agata, and Granada, with approximately $140 \mathrm{~g} /$ fruit. The lightest average fruit weights were observed in the early cultivars BRS_Libra, Precocinho, and Pepita, with approximately $80 \mathrm{~g} /$ fruit. The general mean of the most relevant genotypes was approximately $120 \mathrm{~g} /$ fruit.

In the yield evaluation (Figure $3 \mathrm{f}$ ), cultivars Aldrighi and Cerrito presented averages with values of approximately $38 \mathrm{~kg} /$ plant and were more productive. Cultivars BRS Libra and Granada with productions in BLUP values close to $21 \mathrm{~kg} / \mathrm{plant}$ presented the lowest yields. The general mean of the BLUP value was approximately $30 \mathrm{~kg} / \mathrm{plant}$.

\section{Genetic diversity}

BLUP values for cycle, yield, and brix traits were submitted to cluster analysis by Euclidean distance. Afterwards, considering this group of traits, four groups were formed (Figure 4). The largest group was formed by eight genotypes, cultivars Maciel, Eldorado, Onix, Jubileu, Leonense, Jade, Esmeralda, and Âmbar. The smallest group was formed by three genotypes, cultivars BRS Libra, Pepita, and Precocinho.

\section{Discussion}

The priority goals at the beginning of the breeding program were to offer alternatives for cultivars adapted to the south of Brazil and to extend the period of harvest season, which by then, began in late December or in the first half of January, with the harvest of fruits from cultivar Aldrighi (Medeiros and Raseira, 1998). Until the mid-1970s, this was achieved with the development of late-maturing cultivars. It was only at the end of this decade that the first early-maturing cultivar were obtained, being emphasized after 1984 and mainly in the last 10 years (Figure 1), when it is possible to observe a reduction in the number of days until maturation. The cultivar Diamante was the first to allow significant anticipation of the harvest, which occurred approximately 20 days earlier (Medeiros and Raseira, 1998) than cultivar 
Aldrighi, the peach cultivar planted for the canneries, when the breeding program started. The plant of cv. Diamante was selected from seedlings of the progeny obtained from crossing cv. Convenio, with pollen of at he selection from the Estação Experimental de Taquari/RS, named Pelotas 77. 'Convenio' was the result of open pollination of a cross between the cvs. Amsdem and Abóbora, while Pelotas 77 originated from open pollination of seedlings of the cross between the fresh peach cultivar Cardeal and a canning peach selection that is, ('Cardeal' $\times$ ' Aldrighi') Pl (Table 1). Thus, it is proved that in order to obtain the first very early-maturing cultivars, hybridizations with table peach genotypes was necessary, and in order to achieve the desirable traits for processing, in general, a new hybridization with a canning genotype or another generation is necessary (Byrne et al., 2012).

The earliness of maturation period developed by the Embrapa program was an important step in making fruits available for a greater number of weeks and even months. The beginning of the crop season in the region changed from December to October.

We did not present the data of flowering periods. However, we used it for calculating the cycles. We observed that the beginning of flowering in some cultivars occurred at the beginning of July or even at the end of June (as in cv. Cerrito) until the end of August (as in Santa Áurea). As, in a simplified way, several breeders estimate the chilling requirement of a cultivar for its flowering period, that is, the chill accumulated up to the flowering date of a cultivar would be its chilling requirement (Rawandoozi et al., 2021), we can observe that amplitude regarding the chilling requirement of the cultivars has been increased, although most of them are among those of low chilling requirement.

The result for the number of fruits partly reflects the evaluation system of the two periods studied, since we consider pre-determined intervals and not the actual number of fruits when evaluating degrees. In addition, in the new area - ETC - winter chilling accumulation is lower (Embrapa, 2020) and sometimes insufficient for some cultivars, which leads to decreased and uneven flowering intensity, besides the fact that the soil is shallow and physically and chemically poor, therefore providing less vigorous plants.

Similarly to the comparison by Woyann et al. (2019) while working with wheat, the yield gain in the present study for the 1985-2017 period was $1.23 \%$, that is, an increase of 1.23 $\mathrm{kg}$ for every $100 \mathrm{~kg}$. Extrapolating this idea to $1 \mathrm{ha}$, which produces an average of 15 tons, that would represent $184 \mathrm{~kg}$ more per hectare and year, and between five and six tons more per ha in the 1985-2017 period.

It is interesting to note that we only observed a significantly reduction in production (Figure $3 \mathrm{f}$ ) in early or very early-maturing cultivars. However, the most recently released cultivars, such as BRS Citrino and BRS Jaspe, did not differ significantly from the late-maturing 
and more productive cultivars, showing an evolution of the breeding program in the development of early-maturing genotypes.

Regarding weight, the price differences between fruit considered of first and second type class in the canneries, encourages the search for production of larger fruits, since yield and profit is higher for the producer and yield in the production line is advantageous for the industry. However, the so-called first quality fruit means being over $5.7 \mathrm{~cm}$ in diameter, and any measurement above that has the same value. Diameter is highly correlated with fruit weight, which means that there is no advantage in producing larger fruits beyond a certain average weight, with advantages only for greater numbers of fruit (Raseira et al., 2020). The $5.7 \mathrm{~cm}$ diameter corresponds to an average weight of approximately $100 \mathrm{~g}$ per fruit in most cultivars.

The emphasis on early maturity negatively affected average fruit weight in the first period, since it is difficult to achieve a large size in very early-maturing and/or short-cycle cultivars. However, although the period from 1985 had greater emphasis on obtaining earlyharvest cultivars, maturing in October or early November, the efforts were successful as we still observed positive gain in fruit size. Cultivars like BRS Bonão, Granada, and Maciel certainly contributed to this gain (Raseira et al., 2014).

The temperature and light conditions preceding the harvest of early cultivars are not ideal for sugar accumulation, with cloudy and generally cool days (Byrne et al., 2012) in September. We observed in general from figure 3 that the longest cycle cultivars have a higher TSS content. Cultivars that mature in October in southern Brazil experience relatively few hot and sunny days when compared to those whose fruits mature in December or January. The reduction in cycle means that their period for transformation of carbohydrates into sugars decreases. However, this does not mean that quality regarding taste has been reduced. According to literature data (Cirilli et al., 2016), although soluble solids content and sugar are correlated, this index ranges between 0.33 to 0.72 depending on the presence or not of other active compounds, such as pectins, salts, and organic acids (Byrne et al., 1991). On the other hand, there are variations in soluble solids content even among fruits of the same plant, depending on their position, maturation point (Borsani et al., 2009; Lo Bianco and Rieger, 2002; Lopresti et al., 2016).

It is interesting to observe the position of cv. Aldrighi in Figures 3 (a) to 3 (f), which was considered the most important clone at the beginning of the program that emphasized canning peach genotypes. Regarding the beginning of harvesting, we observed average anticipation of 80 days or more. The fruit development period was shortened by 50 to 60 days and regarding average fruit weight, only four of the genotypes were inferior to 'Aldrighi'. There is a greater number of genotypes with lower soluble solids content than fruits produced by cv. 
Aldrighi corresponding to cultivars maturing in October or early November, when climatic conditions that anticipate their harvesting in the south of the Rio Grande do Sul State correspond to cool and cloudy days. On the other hand, regarding the difference in production, it is largely a consequence of the anticipation of harvest and shorter cycle.

\section{Conclusions}

We observed genetic gain for earliness, with the harvest period extended to more than three months.

There was anticipation of the beginning of the harvest and shortening in the cycle from flowering to maturation, which did not affect fruit size as new cultivars became available from 1985.

A genetic gain for both periods of the peach breeding program of Embrapa was achieved for fruit yield, highlighting a genetic gain of $184 \mathrm{~kg} \mathrm{ha}^{-1} \mathrm{year}^{-1}$ for 1985-2017, corresponding to $1.23 \%$.

\section{References}

Borsani, J., Budde, C.O., Porrini, L., Lauxmann, M.A., Lombardo, V.A., Murray, R., Andreo, C.S., Drincovich, M.F., Lara, M. V., 2009. Carbon metabolism of peach fruit after harvest: Changes in enzymes involved in organic acid and sugar level modifications. Journal of Experimental Botany 60, 1823-1837. https://doi.org/10.1093/jxb/erp055

Breseghello, F., Rangel, P.H.N., De Morais, O.P., 1999. Ganho de produtividade pelo melhoramento genético do arroz irrigado no Nordeste do Brasil. Pesquisa Agropecuaria Brasileira.

Byrne, D.H., Nikolic, A.N., Burns, E.E., 1991. Variability in Sugars, Acids, Firmness, and Color Characteristics of 12 Peach Genotypes. Journal of the American Society for Horticultural Science 116, 1004-1006. https://doi.org/10.21273/JASHS.116.6.1004

Byrne, D.H., Raseira, M.B., Bassi, D., Piagnani, M.C., Gasic, K., Reighard, G.L., Moreno, M.A., Pérez, S., 2012. Peach, in: Badenes, M.L., Byrne, D.H. (Eds.), Fruit Breeding. Springer US, Boston, MA, pp. 505-569. https://doi.org/10.1007/978-1-4419-0763-9_14

Cirilli, M., Bassi, D., Ciacciulli, A., 2016. Sugars in peach fruit: a breeding perspective. Horticulture Research 3, 15067. https://doi.org/10.1038/hortres.2015.67

Corrêa, E.R., Nardino, M., Barros, W.S., Raseira, M.D.C.B., 2019. Genetic progress of the peach breeding program of embrapa over 16 years. Crop Breeding and Applied Biotechnology 19, 319-328. https://doi.org/10.1590/1984-70332019v19n3a44

Embrapa, 2020. Horas de Frio: Maio - Setembro/2020. 
Hoffmann, R., and Vieira, S. (1987). Análise de regressão: uma introdução à economia (2a. ed.). Piracicaba, SP: Hucitec.

Lo Bianco, R., Rieger, M., 2002. Partitioning of Sorbitol and Sucrose Catabolism within Peach Fruit. Journal of the American Society for Horticultural Science. American Society for Horticultural Science 127, 115-121. https://doi.org/10.21273/JASHS.127.1.115

Lopresti, J., Goodwin, I., Stefanelli, D., Holford, P., McGlasson, B., Golding, J., 2016. Understanding the factors affecting within-tree variation in soluble solids concentration in peaches and nectarines. Acta Horticulturae 249-256. https://doi.org/10.17660/ActaHortic.2016.1130.37

Medeiros, C.A.B., Raseira, M.D.C.B., 1998. A cultura do pessegueiro. Embrapa - Centro de Pesquisa Agropecuária Clima Temperado, Pelotas, RS.

Olivoto, T., Lúcio, A., 2020. Metan: an R package for multi-environment trial analysis. . 11:783-789 doi:10.1111/2041-210X.13384. Methods Ecology Evolution 11, 783-789. https://doi.org/10.1111/2041-210X.13384

Raseira, M.C.B., Franzon, R.C., Pereira, J.F.M., Scaranari, C., 2015. The first peach cultivars protected in Brazil. Acta Horticulturae 1084, 39-44. https://doi.org/10.17660/actahortic.2015.1084.3

Raseira, M.D.C.B., 2010. Pêssego Cultivar BRS Libra. Revista Brasileira de Fruticultura 32, 961-1296.

Raseira, M.D.C.B., Franzon, R.C., Feldberg, N.P., Scaranari, C., Pereira, J.F.M., 2020. BRS Jaspe: A processing peach cultivar for low chill areas. Crop Breeding and Applied Biotechnology 20, 3-6. https://doi.org/10.1590/1984-70332020v20n1c5

Raseira, M.D.C.B., Franzon, R.C., Pereira, J.F.M., Scaranari, C., Feldberg, N.P., 2018. Peach cultivar BRS citrino. Crop Breeding and Applied Biotechnology 18, 234-236. https://doi.org/10.1590/1984-70332018v18n2a34

Raseira, M.D.C.B., Pereira, J.F.M., Carvalho, F.L.C., 2014. Pessegueiro, 1st ed. Embrapa, Brasília, DF.

Rawandoozi, Z., Hartmann, T., Byrne, D., Carpenedo, S., 2021. Heritability, Correlation, and Genotype by Environment Interaction of Phenological and Fruit Quality Traits in Peach. Journal of the American Society for Horticultural Science 146, 56-67. https://doi.org/10.21273/JASHS04990-20

SAS Institute, 2014. Statisctical Analysyi System. Version 9.4 STAT/SAS Software.

Wickham, H., 2016. ggplot2 -Positioning Elegant Graphics for Data Analysis, Springer, Use R! Springer International Publishing, Cham. https://doi.org/10.1007/978-3-319-24277-4

Woyann, L.G., Zdziarski, A.D., Zanella, R., Rosa, A.C., de Castro, R.L., Caierão, E., Toigo, 

M.D.C., Storck, L., Wu, J., Benin, G., 2019. Genetic gain over 30 years of spring wheat

Crop

Science

59 , 2036-2045. https://doi.org/10.2135/cropsci2019.02.0136 
Table 1: List of the 52 genotypes analyzed in 53 years and their pedigree, Embrapa Temperate Agriculture, Pelotas/RS-Brazil, 2021

\begin{tabular}{|c|c|c|c|c|c|c|c|}
\hline Cultivar & FP & PP & FPFP & & FPPP & PPFP & PPPP \\
\hline Abóbora & Introd. José melo, colonia Pelotas & & & & & & \\
\hline Agata & 68201104XC2R19T182 & PL & 682011041 & & C2R19T182 & Both uknown for being PL & \\
\hline Aldrighi & $\begin{array}{l}\text { Introd.ArthurKaster-SantaEulalia- } \\
\text { PEL/RS }\end{array}$ & & & & & & \\
\hline Alpes & Aldrighi & Tapes & unkown & & & Lake City & $\begin{array}{l}\text { Intermediário (S 56- } \\
\text { 32) }\end{array}$ \\
\hline Âmbar & Esmeralda & Conserva555 & Alpes & & RR37201 & Ambr.Perret x Cerrito & \\
\hline Ametista & AlpesxRR31-201 & PL & Alpes & & RR31-201 & Both uknown for being PL & \\
\hline Atenas & Jade & $\mathrm{Pl}$ & Alpes & & RR53272 & Both uknown for being PL & \\
\hline Bolinha & Prov. Aldrighi & & & & & & \\
\hline Bonão & Conserva 594 & Pepita & $\begin{array}{l}\text { Capdeboscq } \\
\text { Madrugador }\end{array}$ & $\mathrm{x}$ & PL & Precocinho & PL \\
\hline $\mathrm{Br} 2$ & Aldrighi & Cerrito & Aldrighi? & & $?$ & LakeCityXIntermediario & \\
\hline $\mathrm{Br} 4$ & Conserva 162 & PL & Aldrighi & & Cerrito & unkown & unk. \\
\hline Br6 & Amb. Perret & Tapes & unkown & & $\begin{array}{ll}\text { Intr. } & \text { unkownLake } \\
\text { cityIntermediario } & \end{array}$ & lake city & Intermediario \\
\hline Brandolasco & intr. Unkown & & & & & & \\
\hline Brilhante & Convenio & Pelotas 76 & AmsdemXAbobora & & PL & Aldrighix Taq. Precoce & unk. \\
\hline Capdeboscq & Lake cityx Intermediario & Lake City & Intermediari & & & unk. & unk. \\
\hline Cerrito & LakeCityXIntermediario & PL & LakeCity & & Intermediário & Both uknown for being PL & \\
\hline Citrino & Conserva1104 & Leonense & Eldorado & & Sensação & (Provavel) Brilhante & NJC97 X PL \\
\hline Convênio & AmsdemxAbobora & PL & Amsdem & & Abobora & unk. & unk. \\
\hline Corisco & Aldr. X Taq Prec. & PL & Aldrighi & & Taq Precoce & unk. & unk. \\
\hline Diamante & Convenio & Pelotas 77 & AmsdemxAbobora & & PL & (CARDEAL X ALDRIGHI) & $\mathrm{PL}$ \\
\hline Eldorado & Gaudéri & Serrano & Del.xInterludio & & PL & unk. & unk. \\
\hline Esmeralda & Alpes & RR37201 & Aldrighi & & TAPES & American introd. & \\
\hline Farrapos & Edmundo Perretx Aldr. & PL & Edmundo Perret & & Aldrighi & unk. & unk. \\
\hline Granada & Granito & PL & Alpes & & Cons 102 & unk. & unk. \\
\hline Granito & Alpes & Cons 102 & Aldrighi & & Tapes & intr USA & \\
\hline Jade & Alpes & RR 53272 & Aldrighi & & Tapes & intr. USA & \\
\hline Jubileu & Bolinha & sel.intr.7-28 & Aldrighi & & PL & Introd. from Mexico & \\
\hline Leonense & Brilhantex NJC97 & PL & Brilhante & & NJC 97 & unk. & unk. \\
\hline
\end{tabular}




\begin{tabular}{|c|c|c|c|c|c|c|c|}
\hline Libra & Cons 594 & Pepita & (Capx Madrugador) & PL & Precocinho & & unk. \\
\hline Lord & Ab'boraxTaq.Precoce & PL & Abóbora & Taq.Precoce & unk. & & unk. \\
\hline Maciel & Conserva171 & Conserva334 & Aldrighi & Pelotas76 & $\begin{array}{l}712128 \text { Introduçãode } \\
\text { Univ. }\end{array}$ & Rutgers & \\
\hline Madrugador & AbóboraxTaq. Precoce & PL & Abóbora & Taq. Precoce & unk. & & unk. \\
\hline Matutino & Aldrighix Taq.Precoce PL & & Aldrighi & Taq Precoce & unk. & & unk. \\
\hline Magno & AmbrosioPerret & TAPES & Introdução & & LAKECity & & $\begin{array}{l}\text { Intermediário (S 56- } \\
\text { 32) }\end{array}$ \\
\hline $\begin{array}{l}\text { Morro } \\
\text { Redondo }\end{array}$ & Lake Cityx Intermediario & PL & Lake City & Intermediario & unk. & & unk. \\
\hline Olímpia & Bolinha & intr 7-28 & Prov. Aldrighi & & & & introdução \\
\hline Ônix & Farrapos & Diamante & Edmundo PerretxAldr. & PL & Convenio & & Pel 77 \\
\hline Pepita & Precocinho & PL & Convenio & Pelotas 77 & unk. & & unk. \\
\hline Piratini & Ambrosio Perret & Tapes & Intr & Lake city & Intermediario & & \\
\hline Ponteiro & Capdeboscq & Mimoso & Lake city & Intermediário & Leader & & Prelúdio \\
\hline Precocinho & Diamante & PL & Convenio & Pelotas77 & Both uknown for being PL & & \\
\hline Real & Intr. De Campinas SP & & & & & & \\
\hline Rio Grandense & BrilhantexNJC97 & PL & Brilhante & NJC97 & unk. & & unk. \\
\hline Safira & Ambrosio Perret & Cerrito & Intr. unk. & LakecityxInt. & unk. & & unk. \\
\hline Santa Aurea & Cerrito & NJC 88 & LakeCityXIntermediario & PL & Intr USA & & $*$ \\
\hline Santa Helena & Prov. Intr. Da Colonia Sta Helena & & & & & & \\
\hline Sensação & Granito & PL & & & & & \\
\hline Tarumã & Aldrighi & $\begin{array}{l}\text { AmsdemxAbobora)PLun } \\
\mathrm{k}\end{array}$ & & unk & AmsdemxAbobora & & Unk \\
\hline Topazio & Convenio & Pelotas 76 & AmsdemxAbobora & PL & Aldr.xTaq Precoce & & PL \\
\hline Turmalina & Cons 334 & Cons.594 & Intr.71.21.28 & & Cap x Madrugador & & PL \\
\hline Turquesa & ConvenioxCerrito & PL & Convenio & Cerrito & unk & & unk. \\
\hline Vanguarda & AlpesxTT53.272 & PL & AldrighiTapes & & Intr. & & \\
\hline
\end{tabular}

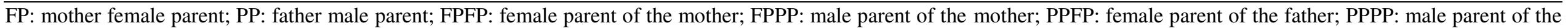
father. 
Table 2: Estimates of variance components for random effects and significance of the fixed effect (year) of the generalized linear mixed model for each variable and period, Embrapa Temperate Agriculture, Pelotas/RS-Brazil, 2021

\begin{tabular}{|c|c|c|c|c|c|c|}
\hline \multirow{2}{*}{ Trait } & \multirow{2}{*}{$\mathrm{n}^{\circ}$ genotype } & \multirow{2}{*}{$\mathrm{n}^{\mathrm{o}}$ year $^{*}$} & \multicolumn{2}{|c|}{ Covariance Parameter Estimates } & \multicolumn{2}{|c|}{ Tests of fixed effects } \\
\hline & & & Genotype \pm SE & Residual \pm SE & Year - F value & $\operatorname{Pr}>\mathrm{F}$ \\
\hline MAT (64 -84) & 288 & 16 & $523.42 \pm 125.4$ & $43.68 \pm 3.6$ & 27.47 & $<0.0001$ \\
\hline MAT (85-17) & 732 & 32 & $622.60 \pm 127.4$ & $62.39 \pm 3.3$ & 14.85 & $<0.0001$ \\
\hline FDP I (64 - 84) & 276 & 16 & $457.40 \pm 114.4$ & $79.50 \pm 6.8$ & 4.60 & $<0.0001$ \\
\hline FDP I (85-17) & 740 & 33 & $463.98 \pm 95.2$ & $107.12 \pm 5.6$ & 10.32 & $<0.0001$ \\
\hline FDP II (64-84) & 261 & 16 & $468.52 \pm 115.6$ & $54.23 \pm 4.7$ & 6.62 & $<0.0001$ \\
\hline FDP II (85-17) & 654 & 33 & $477.97 \pm 100.9$ & $88.37 \pm 4.9$ & 8.97 & $<0.0001$ \\
\hline NF (64-84) & 181 & 13 & $17180.00 \pm 6716.8$ & $40314 \pm 4292.5$ & 8.18 & $<0.0001$ \\
\hline NF (85-17) & 918 & 29 & $3588.28 \pm 848.8$ & $12136 \pm 566.7$ & 19.00 & $<0.0001$ \\
\hline FM (64-84) & 272 & 16 & $319.17 \pm 100.47$ & $497.20 \pm 42.92$ & 7.28 & $<0.0001$ \\
\hline FM (85-17) & 774 & 33 & $401.48 \pm 89.32$ & $590.14 \pm 29.98$ & 6.20 & $<0.0001$ \\
\hline PD (64-84) & 165 & 12 & $304.77 \pm 119.42$ & $569.72 \pm 63.9$ & 7.99 & $<0.0001$ \\
\hline PD (85-17) & 519 & 27 & $22.46 \pm 8.39$ & $189.91 \pm 11.78$ & 8.88 & $<0.0001$ \\
\hline BRIX (85 -17) & 576 & 30 & $4.12 \pm 0.91$ & $2.19 \pm 0.13$ & 7.79 & $<0.0001$ \\
\hline
\end{tabular}


Table 3: Results of descriptive statistics for the variables evaluated, Embrapa Temperate Agriculture, Pelotas/RS-Brazil, 2021

\begin{tabular}{|c|c|c|c|c|c|c|}
\hline Statistics (unit) & Min & $\mathrm{q}_{1}$ & mean & $\mathrm{q}_{3}$ & sd & $\max$ \\
\hline MAT_1964 (nº days) & 293.0 & 345.0 & 362.5 & 380.0 & 23.6 & 422.0 \\
\hline MAT_1985 (nº days) & 267.0 & 324.0 & 341.2 & 361.0 & 25.4 & 401.0 \\
\hline FDP I_1964 (nº days) & 100.0 & 138.0 & 156.0 & 172.0 & 22.1 & 209.0 \\
\hline FDP I_1985 (nº days) & 77.0 & 121.0 & 138.7 & 156.0 & 23.9 & 219.0 \\
\hline FDP II_1964 (nº days) & 89.0 & 127.0 & 145.2 & 162.0 & 21.7 & 199.0 \\
\hline FDP II_1985 (nº days) & 66.0 & 110.0 & 128.4 & 147.0 & 23.9 & 203.0 \\
\hline NF_1964 (no fruit) & 10 & 140.0 & 364.61 & 550.0 & 262.24 & 1010.0 \\
\hline NF_1985 ( $n^{\circ}$ fruit) & 6.0 & 146.0 & 247.9 & 350.0 & 147.4 & 698.0 \\
\hline FW_1964 (g) & 30.0 & 88.0 & 107.16 & 125.0 & 30.11 & 216.0 \\
\hline FW_1985 (g) & 37.0 & 89.5 & 113.3 & 132.0 & 33.7 & 288.9 \\
\hline TSS $\left({ }^{\circ}\right.$ Brix $)$ & 5.7 & 11.0 & 12.8 & 14.7 & 2.6 & 19.9 \\
\hline PD_1964 (kg) & 0.73 & 13.44 & 39.28 & 66.73 & 31.19 & 123.20 \\
\hline PD_1985 (kg) & 0.82 & 14.02 & 26.24 & 37.80 & 16.64 & 101.91 \\
\hline
\end{tabular}

MAT_196\& MAT_1985:Fruit maturation in the 1964-1984 and 1985-2017 periods (respectively);FDP I_1964\& FDP I_1985: fruit development period (considering the beginning of flowering and maturing) in the 1964-1984 and 1985-2017 periods (respectively); FDP II_1964 \& FDP II_1985: fruit development period (considering full flowering and maturation) in the 1964-1984 and 1985-2017 periods (respectively); NF_1964 \& NF_1985: number of fruits in the 1964-1984 and 1985-2017 periods (respectively); FW_1964 \& FW_1985: fruit weight in the 19641984 and 1985-2017 periods (respectively);TSS: soluble solids content in the fruits; PD_1964 \& 1985: fruit weight in the 1964-1984 and 1985-2017 periods (respectively);Min: minimum observed value; $\mathrm{q}_{1}$ : first quartile; Mean: arithmetic mean; $\mathrm{q}_{3}$ : third quartile; sd: sample standard deviation and Max: maximum observed value. Fruit maturing in the 1964-1984 and 1985-2017 periods, MAT_1964-1984 and MAT_1985-2017. 
Table 4: Genetic gain (mean) of each variable for maturing period, fruit development period, number of fruits, and production per plant in the 1964-1984 and 1985-2017 periods, Embrapa Temperate Agriculture, Pelotas/RS-Brazil, 2021

\begin{tabular}{llllllll}
\hline Parameter & $\mathrm{B}_{0}$ & $\mathrm{~B}_{1}$ & $\begin{array}{l}\text { tcalc- } \\
\text { value }\end{array}$ & $\begin{array}{l}\text { t tab- } \\
\text { value }\end{array}$ & $\operatorname{Pr}>|t|$ & $\begin{array}{l}\text { Ggen (annual } \\
\%)\end{array}$ & $\begin{array}{l}\text { Ggen (full } \\
\%)\end{array}$ \\
\hline MAT (64 -84) & 359.14 & 0.19 & 1.97 & 2.1448 & 0.06895 & 0.05 & 0.83 \\
MAT (85-17) & 349.87 & -0.19 & -5.60 & 2.0423 & 0.00000 & -0.05 & -1.71 \\
FDP I (64 - 84) & 154.55 & -0.14 & -1.11 & 2.1448 & 0.28570 & -0.09 & -1.49 \\
FDP I (85-17) & 145.70 & -0.12 & -2.85 & 2.0395 & 0.00770 & -0.08 & -2.70 \\
FDP II (64-84) & 142.52 & -0.04 & -0.32 & 2.1448 & 0.75369 & -0.02 & -0.41 \\
FDP II (85-17) & 136.56 & -0.18 & -4.59 & 2.0395 & 0.00007 & -0.14 & -4.34 \\
NF (64-84) & 225.66 & 17.99 & 3.69 & 2.2010 & 0.00356 & 7.97 & 103.6 \\
NF (85-17) & 231.80 & 0.90 & 2.23 & 2.0518 & 0.03426 & 0.39 & 11.22 \\
FW (64-84) & 108.60 & -0.14 & -0.45 & 2.1448 & 0.65960 & -0.13 & -2.06 \\
FW (85-17) & 104.51 & 0.40 & 4.05 & 2.0395 & 0.00032 & 0.38 & 12.56 \\
PD (64-84) & 16.15 & 3.13 & 5.14 & 2.2281 & 0.00044 & 19.38 & 232.57 \\
PD (85-17) & 22.71 & 0.28 & 3.83 & 2.0595 & 0.00077 & 1.23 & 33.29 \\
BRIX (85-17) & 13.18 & -0.01 & -1.91 & 2.0484 & 0.06643 & -0.11 & -3.24 \\
\hline
\end{tabular}

$\mathrm{B}_{0}$ : intercept, $\mathrm{B}_{1}$ : slope; Ggen (annual\%): annual genetic gain and Ggen (full\%): total genetic gain. MAT_196 \& MAT_1985:Fruit maturing in the 1964-1984 and 1985-2017 periods (respectively); FDP I_1964 \& FDP I_1985: fruit development period (considering the beginning of flowering and maturing) in the 1964-1984 and 1985-2017 periods (respectively); FDP II_1964 \& FDP II_1985: fruit development period (considering full flowering and maturing) in the 1964-1984 and 1985-2017 periods (respectively); NF_1964 \& NF_1985: number of fruits in the 1964-1984 and 1985-2017 periods (respectively); FW_1964 \& FW_1985: fruit weight in the 1964-1984 and 19852017 periods (respectively); TSS: soluble solids content in the fruits; PD_1964 \& 1985: fruit weight in the 19641984 and 1985-2017 periods (respectively); 

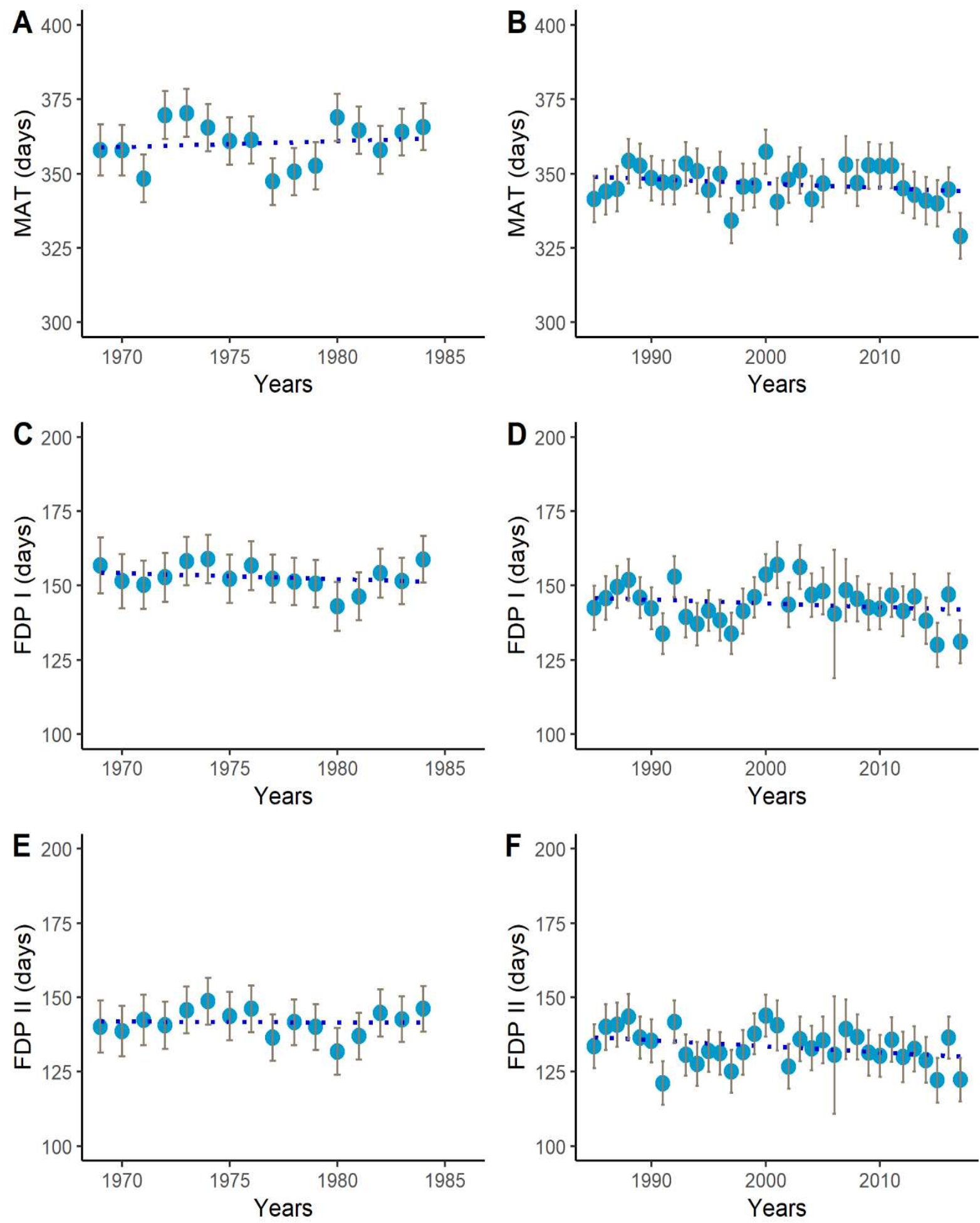

Figure 1: General means of the genotypes in each year studied. (A) Peach fruit maturing during the period 19641984 period. (B) Peach fruit maturing during the 1985-2017 period. (C) Cycle considering the beginning of flowering during the 1964-1984 period. (D) Cycle considering the beginning of flowering during the 1985-2017 period. (E) Cycle considering the beginning of full flowering during the 1964-1984 period. (F) Cycle considering the beginning of full flowering during the 1985-2017 period. The circles represent the general and annual means and the vertical bars represent the confidence intervals for the means, Embrapa Temperate Agriculture, Pelotas/RSBrazil, 2021. 

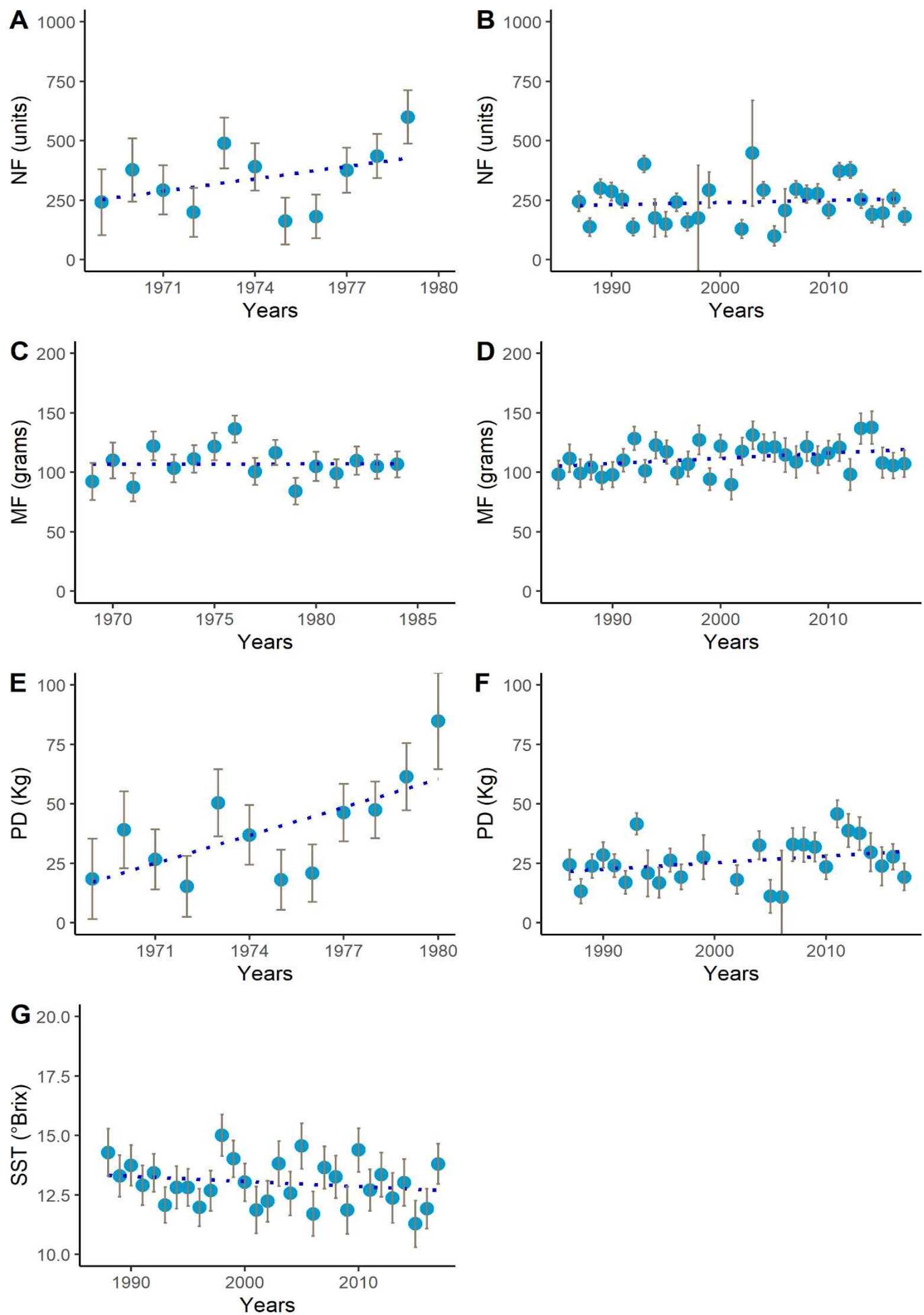

Figure 2: Comparison between general means of the canning peach genotypes in each year. (A) Number of fruits during the 1964-1984 period. (B) Number of fruits during the 1985-2017 period. (C) Fruit weight during the 19641984 period. (D) Fruit weight during the $1985-2017$ period. (E) Production during the 1964-1984 period. (F) Production during the 1985-2017 period. (G) Mean total soluble solids content in ${ }^{\circ}$ Brix during the 1985-2017 period. The circles represent the general and annual means and the vertical bars represent the confidence intervals for the means, Embrapa Temperate Agriculture, Pelotas/RS-Brazil, 2021. 
(a)

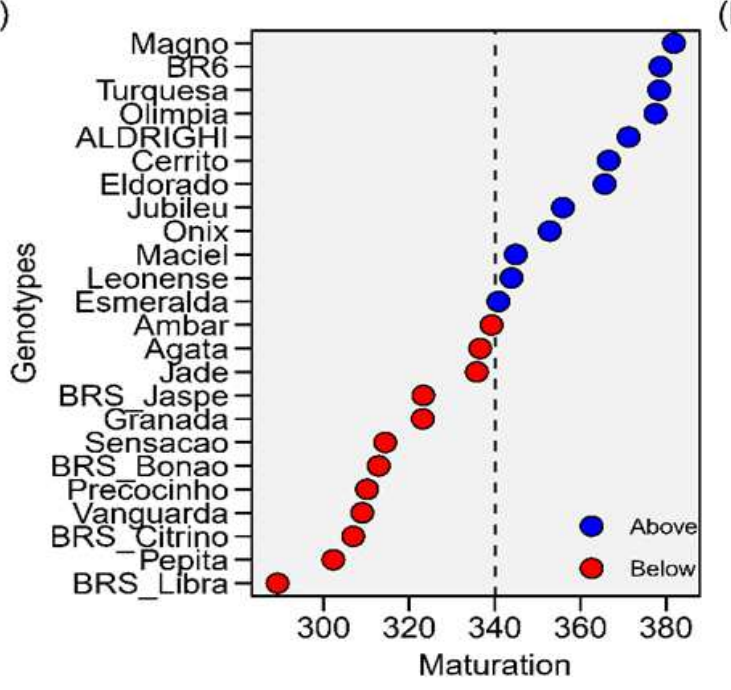

(d)

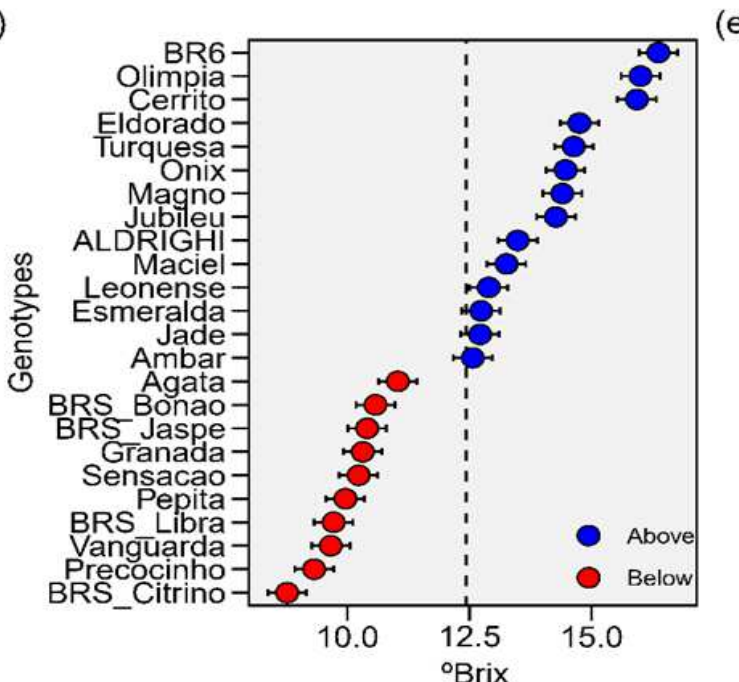

(b)

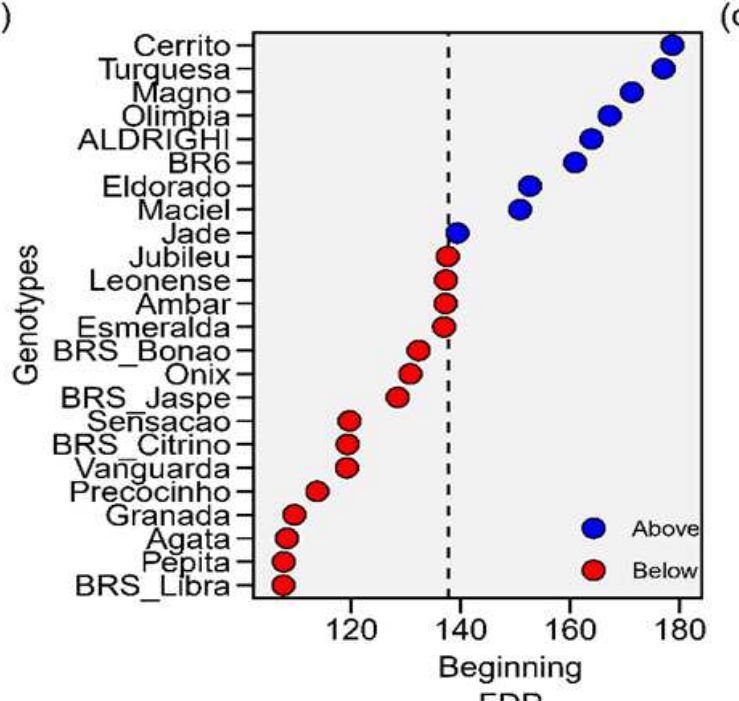

(e)

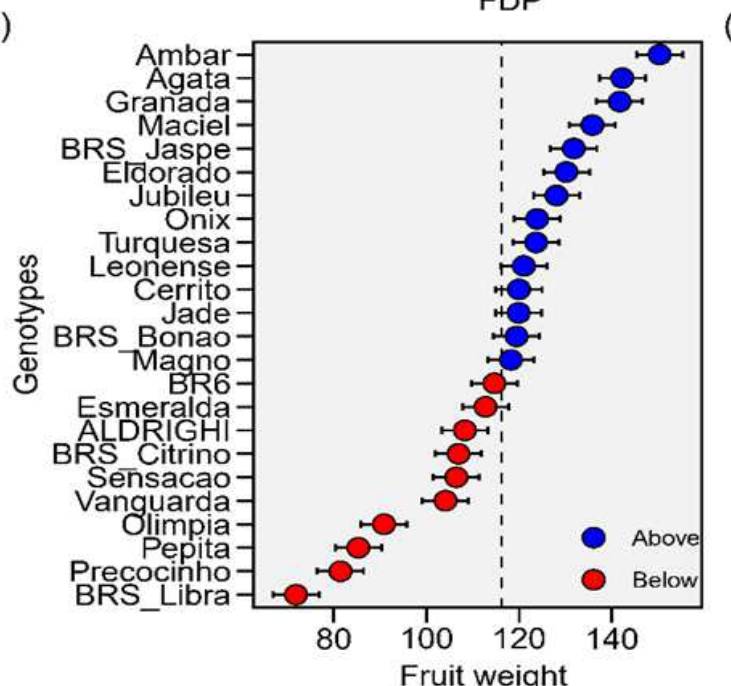

(c)

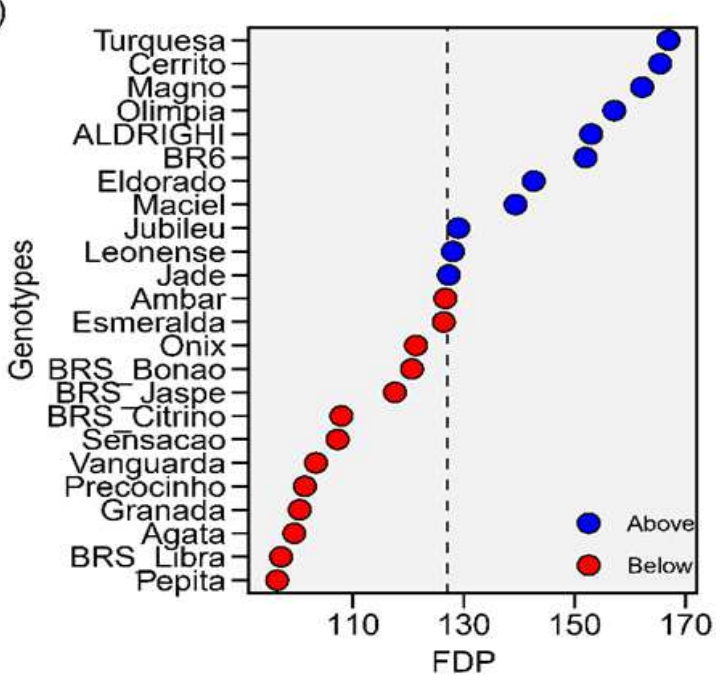

(f)

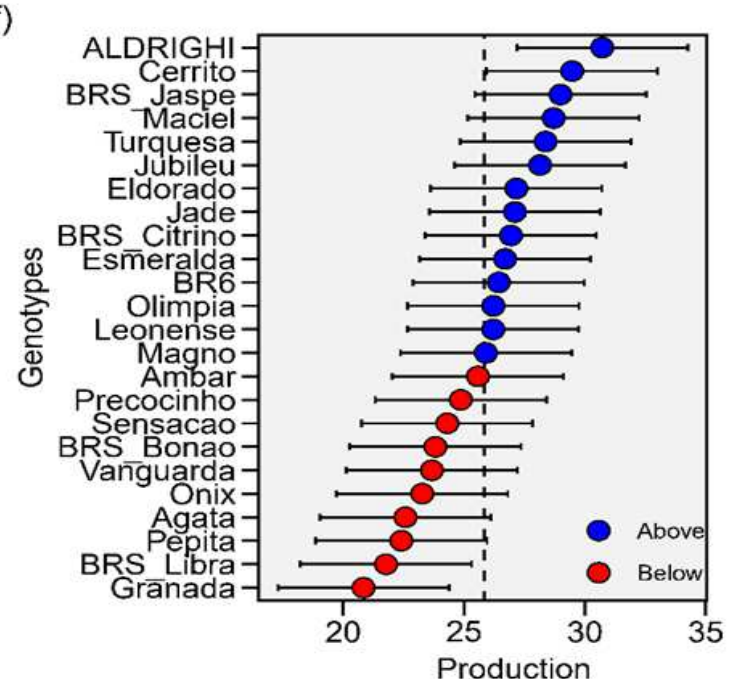

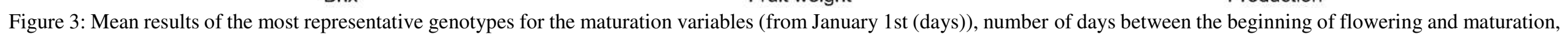
FDP, number of days between full flowering and maturation, ${ }^{\circ}$ Brix, fruit weight (grams) and production in kg/plant, Embrapa Temperate Agriculture, Pelotas/RS-Brazil, 2021. 


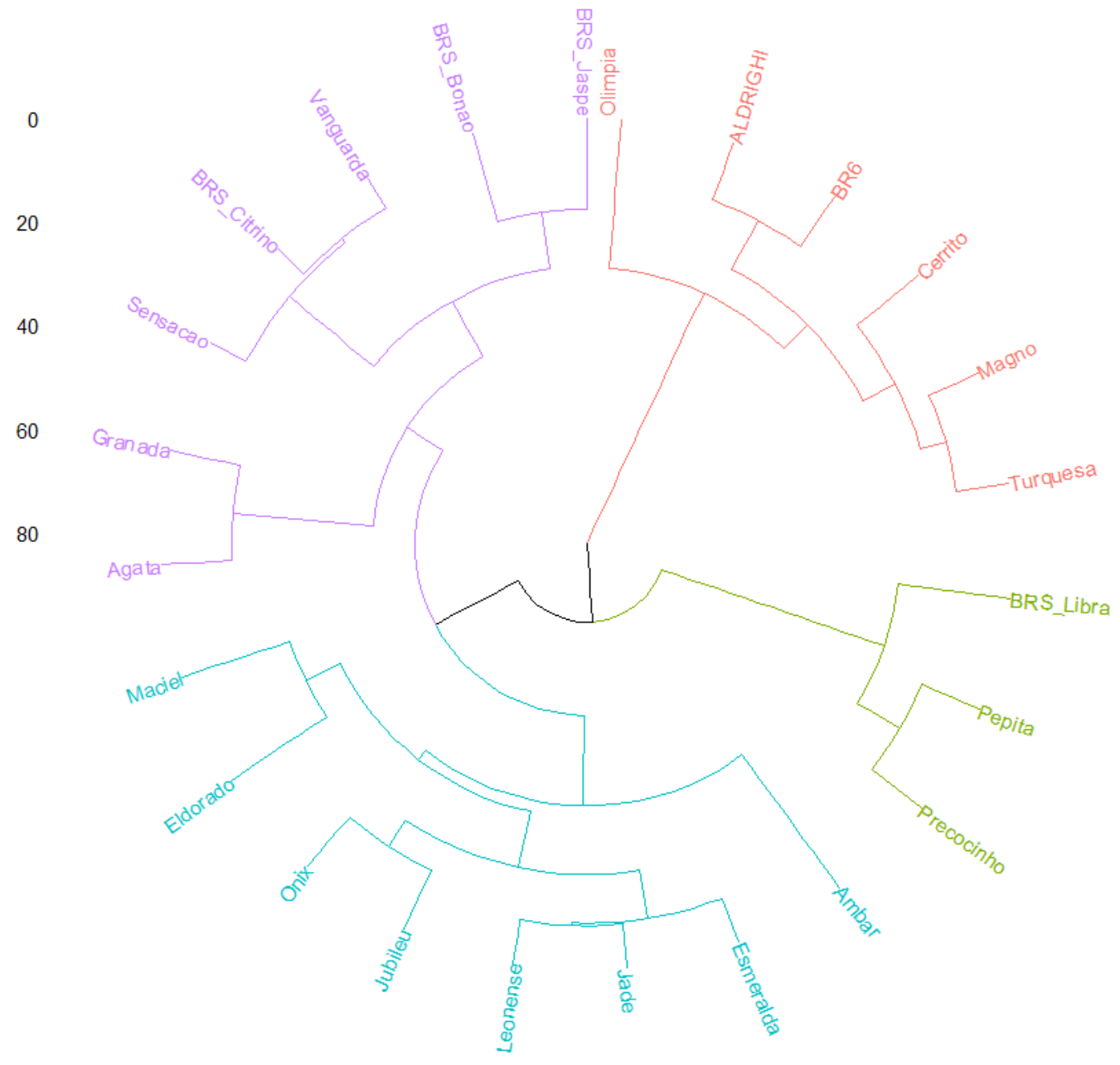

Figure 4: Dendrogram of the currently most planted and cultivated peach cultivars, Embrapa Temperate Agriculture, Pelotas/RS-Brazil, 2021. 